\title{
m-TOR Inhibitors in Kidney Transplantation: A Comprehensive Review
}

\author{
Mekki $\mathbf{M}^{1,2}$, Bridson $\mathrm{JM}^{2}$, Sharma $\mathrm{A}^{2,3}$ and Halawa $\mathrm{A}^{2,4^{*}}$ \\ ${ }^{1}$ Renal Department, Royal Shrewsbury Hospital, UK \\ ${ }^{2}$ Faculty of Health and Science, Institute of Learning and Teaching, University of Liverpool, UK \\ ${ }^{3}$ Royal Liverpool University Hospital, Liverpool, UK \\ ${ }^{4}$ Sheffield Teaching Hospitals, Sheffield, UK
}

"Corresponding author: Ahmed Halawa, MD PhD, Consultant Transplant Surgeon, Sheffield Teaching Hospital, University of Sheffield-University of Liverpool, United Kingdom, Tel: +00447787542128; E-mail: ahmed.halawa@sth.nhs.uk

Received date: July 2, 2017; Accepted date: July 11, 2017; Published date: July 12, 2017

Copyright: (C) 2017 Mekki M, et al. This is an open-access article distributed under the terms of the Creative Commons Attribution License, which permits unrestricted use, distribution, and reproduction in any medium, provided the original author and source are credited.

\begin{abstract}
Mammalian target of rapamaycin inhibitors (mTOR-I) has been in use in kidney transplantation for over two decades. Since their introduction, they have been used in different combination immunosuppressant for low risk group renal transplantation. They have been in use in the various (Calcineurin inhibitors) CNI-free protocols, either as De novo regiments, or by conversion from CNIs at a later stage. Many of these studies reported comparable graft rejection rate and a better kidney function (eGFR) compared to standard CNI protocols. Also mTOR-I when used in combination with CNIs, facilitated the use of lower doses of CNIs with the resultant reduction of CNI related side effects, without seriously compromising graft outcome. They are of particular interest among certain group of renal transplant recipients, including those with malignancy, post-transplant encapsulating peritoneal scelorosis, CMV and BK virus infections. Moreover, protocols containing mTOR-I showed comparable results to standard protocols among recipients of kidneys from extended-criteria transplantation. However, only few reports studied their use in high risk group renal transplantation, with variable outcomes. There is a noticeable drop in their popularity in the recent years, and their use was associated with multiple adverse events, in addition to a recent concern of their link to increased mortality. Also, a high discontinuation rate was demonstrated across many of the studies available to date. More studies are still needed to clarify the above-mentioned concerns.
\end{abstract}

Keywords: Mammalian target of rapamycin inhibitors; Renal transplantation; Immunosuppressant

\section{Methods and Data Collection}

Search of the literature including pubmed, NCBI and Google search engine using the key words immunosuppression, mammalian target of rapamycin inhibitors, and kidney transplantation. All relevant articles which were provided in English were reviewed.

\section{Introduction and Overview of Immunosuppressant in Kidney Transplantation}

Recent years witnessed a substantial improvement in the field of kidney transplantation. The rate of acute allograft rejection (AR) has reduced in both cadaveric and living donors renal transplantation, with an increased graft survival in the first year [1,2]. Graft survival after the first year of transplantation has been improving [2]. Since the first kidney transplantation in the 1960s [3], there has been an observed increase in the development and introduction of newer immunosuppressive agents [1]. In 1960s, kidney transplantation immunosuppressant protocols consisted of total body irradiation, steroids, and azathioprine (Aza) [4]. Cyclosporine A (CyA), a calcineurin inhibitor (CNI), was introduced in 1980s. It provided a dramatic reduction of acute rejection episodes and was shown to improve the graft survival in the first few years of transplantation $[5,6]$. In the 1990s onwards, various combinations of immunosuppressive medications were introduced into practice in addition to induction therapy [2,7]. Micro-emulsion formulation of CyA (Neoral) was introduced with subsequent improvement in acute graft rejection compared to the conventional formulation (Sandimmune) [8]. Afterwards prograf, mycophenonlate mofetil (MMF), and mammalian target of rapamycin inhibitors (mTOR-I) were introduced. Induction treatments include anti-thymocyte globulin, basliximab, daclizumab $[2,8]$ and alemtuzumab (Campath) [9]. Accompanying this was the increasing challenge of transplanting higher risk groups including those with more HLA mismatches (Tables $1 \mathrm{~A}$ and 1B) [2], retransplants [10,11], $\mathrm{ABO}$ incompatible [12-15] and patients with preformed donor specific antibodies (DSA) [16,17]. Also there is an observed trend of steroid avoidance/minimization with the adoption of more powerful immunosuppressant [18].

The transplanted kidney got rejected following its recognition by the recipient's immune system. This would be followed by activation of $\mathrm{T}$ cells through the three signal pathway. Signal 1 started upon binding of the $\mathrm{T}$ cell with donor's antigens presented in the context of major histocompatibility complex (MHC). This involves CD3 complex, which is in close proximity to T-cell receptor. Signal 2 involves co-stimulation and involves binging of CD 28 on the surface of T-cells with CD 80 and CD 86 on the dendritic cells. Signal 3 involves activation of calciumcalcineurin pathway and other pathways leading to increased transcription of IL2, CD154, CD25 and other cytokines, which in turn lead to $\mathrm{T}$ cell proliferation.

Immunosuppressive medications target different points in the immune system (Figure 1) [19]. There are 3 stages of immunosuppression: induction, maintenance, and treatment of established rejection. Induction therapy is important in reducing acute rejection and help delay the use of CNI. 
Citation: Mekki M, Bridson JM, Sharma A, Halawa A (2017) m-TOR Inhibitors in Kidney Transplantation: A Comprehensive Review. J Kidney 3:

Page 2 of 12

\begin{tabular}{|c|c|c|c|c|c|c|c|c|}
\hline \multirow[t]{2}{*}{ Year } & \multicolumn{8}{|c|}{ Number of HLA Mis-matches ( $\%$ of renal transplantation in the year) } \\
\hline & 0 & 1 & 2 & 3 & 4 & 5 & 6 & Unknown \\
\hline 1998 & -10.3 & -6.2 & -9.2 & -19.9 & -23.2 & -20.3 & -10.2 & -0.5 \\
\hline 1999 & -11.1 & -6.3 & -8.3 & -18.4 & -22.7 & -21.3 & -11.3 & 0.5 \\
\hline 2000 & -10.5 & -6.5 & -8.5 & -17.6 & -23.2 & -22.3 & -11.2 & -0.3 \\
\hline 2001 & -11.5 & -5 & -8.3 & -18.5 & -22.9 & -21.5 & -12.2 & -0.2 \\
\hline 2002 & -11.5 & -4.1 & -7.7 & -16.8 & -22.6 & -22.7 & -14.1 & -0.4 \\
\hline 2003 & -10.6 & -3.5 & -5.2 & -13.3 & -23.3 & -27.9 & -15.4 & -0.7 \\
\hline 2004 & -12 & -3 & -3.3 & -11.8 & -24.9 & -30.1 & -14.3 & -0.6 \\
\hline 2005 & -12 & -2.4 & -3.3 & -11 & -24.4 & -31.1 & -15.1 & -0.7 \\
\hline 2006 & -10.9 & -2 & -3.3 & -10.8 & -25.1 & -31.1 & -16 & -0.8 \\
\hline 2007 & -12 & -2.2 & -3.7 & -10.6 & -24.7 & -30.6 & -15.4 & -0.8 \\
\hline 2008 & -12.2 & -2 & -3.8 & -11.8 & -23.2 & -30.1 & -16.3 & -0.6 \\
\hline 2009 & -6.8 & -1.4 & -3.9 & -12.4 & -25.8 & -32.1 & -17.3 & -0.5 \\
\hline 2010 & -6.8 & -1.1 & -4 & -13 & -26.3 & -32.1 & -16.1 & -0.6 \\
\hline 2011 & -7.2 & -0.9 & -4 & -13.4 & -27.1 & -31.4 & -15.1 & -0.7 \\
\hline 2012 & -7.5 & -0.9 & -4.1 & -13 & -26.7 & -31.6 & -15.4 & -0.8 \\
\hline
\end{tabular}

Table 1A: Total HLA mismatches among adult kidney transplant recipients, deceased donors. From the OPTN, SRTR report 2012 [2]. OPTN=Organ Procurement and Transplantation Network, SRTR=Scientific.

Medications used for induction can be divided into depleting and non-depleting agents in Table 2 [4]. The use of induction agents, as per the reports of OPTN/SRTR during the years 1998-2012, is depicted in Figure 2 [2].

Basiliximab and daclizumab bind to CD 25 to inhibit IL2 production, which is necessary for T-cell activation and proliferation. Basiliximab is a non-depleting humanized chimeric monoclonal antibody (75\% human and $25 \%$ mouse). It has greater affinity to CD25 than daclizumab (which is a humanized monoclonal antibody with $90 \%$ human and 10 mouse) [4]. Basiliximab is shown to have similar efficacy and better safety profile compared to Anti thymoglobulin [21-23]. It reduces graft rejection and mortality compared to placebo without increasing adverse effects, which include infection and malignancy $[22,23]$. The dose for basiliximab is shown in Table 2 [20]. Equine anti-thymocyte globulin (ATGAM) and rabbit anti-thymocyte globulin (Thymoglobulin) are polyclonal depleting agents used for induction of immunosuppression in kidney transplantation [4]. Their doses are shown in Table 2 [20]. Both ATGAM and thymoglobulin contain antibodies active against several T-cell antigens including CD2, CD3, CD4, CD5, CD8, CD11, CD18, CD45, anti $\beta$-2- microglobulin and anti HLA DR antibodies [24]. Thymoglobulin was also shown to induce complement-independent apoptosis of naive and activated $\mathrm{B}$ cells in addition to plasma cells [25]. They are used for induction especially in high-risk groups and also for treatment of acute rejection $[21,26]$. The main side effect of thymoglobulin and ATGAM include cytokine release syndrome [27], infections [28] and malignancy especially post-transplant Lymphoproliferative diseases (PTLD) $[29,30]$. There is a recent concern of graft loss on the long term among patients who had developed serum sickness following induction with thymoglobulin [31].

The newer depleting agent alemtuzumab (Campath ${ }^{\circ}$ ) is a humanized monoclonal antibody directed against CD52 of T-cells [4]. Dose and side effects of Campath are summarized in Table 2 [20]. It is used as an induction agent in high-risk group [32] and causes profound lymphocyte depletion [33]. Risk of rejection is shown to be lower compared to conventional methyl prednisolone induction [34], without significant increase in malignancy [35]. It is also used for treatment of steroid-resistant acute rejection [36]. Other agents to mention in this context are the ones used in the desensitization protocols for high-risk groups. These include intravenous immunoglobulins (IVIG), plasma exchange, rituximab (anti CD 20) and bortezomib (proteasome inhibitor) [37-40]. Maintenance immunosuppressants include steroids, Calcineurin inhibitors (CNI), anti-proliferatives (azathioprine and mycophenolate mofetil), mTOR-I (Sirolimus and Everolimus), and belatacept. Table 3 summarizes the different maintenance immunosuppressive medications, dosing, and common side effects [20].

Steroids have been in use since the early days of transplantation [4]. They work by binding to steroid receptors and inhibit transcription of cytokine genes and cytokine receptors. Their use is associated with multiple side effects (Table 3) [20], which led to emergence of various regiments minimizing their use in kidney transplantation [18]. There is a noticeable drop of the use of steroid both in the early and late stages of transplantation among renal transplant recipients, over the recent decades in Figure 3 [2]. 
Citation: Mekki M, Bridson JM, Sharma A, Halawa A (2017) m-TOR Inhibitors in Kidney Transplantation: A Comprehensive Review. J Kidney 3:

Page 3 of 12

\begin{tabular}{|c|c|c|c|c|c|c|c|c|}
\hline \multirow[t]{2}{*}{ Year } & \multicolumn{8}{|c|}{ Number of HLA Mis-matches ( $\%$ of renal transplantation in the year) } \\
\hline & 0 & 1 & 2 & 3 & 4 & 5 & 6 & Unknown \\
\hline 1998 & -13.6 & -7.2 & -19.1 & -29.4 & -11 & -10.9 & -5.7 & -3.1 \\
\hline 1999 & -12.1 & -6.9 & -18.8 & -29.1 & -12.4 & -12.4 & -5.4 & -2.8 \\
\hline 2000 & -11.7 & -6.2 & -18.9 & -28 & -12.7 & -14 & -6.5 & -2 \\
\hline 2001 & -11.1 & -6.8 & -18.1 & -28.1 & -12.9 & -14.3 & -7.6 & -1.1 \\
\hline 2002 & -10.8 & -6.5 & -17.3 & -29.1 & -12.7 & -14.9 & -7.8 & -0.8 \\
\hline 2003 & -9.6 & -5.7 & -18.1 & -27.9 & -13.5 & -15.7 & -8.9 & -0.7 \\
\hline 2004 & -9.1 & -5.5 & -16.9 & -28.5 & -13.5 & -16.3 & -9.2 & -0.9 \\
\hline 2005 & -8.1 & -5.9 & -17.2 & -28.1 & -14.3 & -17 & -8.8 & -0.7 \\
\hline 2006 & -9.2 & -5.3 & -16.4 & -27.8 & -14.7 & -16.8 & -9 & -0.7 \\
\hline 2007 & -8.1 & -4.9 & -15.9 & -27.6 & -15.1 & -17.5 & -9.8 & -1 \\
\hline 2008 & -8.8 & -4.7 & -16.8 & -25.9 & -15.3 & -17.5 & -10.1 & -0.9 \\
\hline 2009 & -7.8 & -4.6 & -15.9 & -26.7 & -15.9 & -18.1 & -9.9 & -1 \\
\hline 2010 & -7.8 & -4.2 & -14.7 & -25.1 & -16.4 & -20 & -10.8 & -1 \\
\hline 2011 & -7.8 & -4.4 & -14.1 & -24.9 & -17 & -20.4 & -10.5 & -0.9 \\
\hline 2012 & -6.5 & -4.3 & -13.8 & -24.4 & -17.1 & -19.3 & -11.6 & -3 \\
\hline
\end{tabular}

Table 1B: Total HLA mismatches among kidney transplant recipients, living donors. From the OPTN, SRTR report 2012 [2].

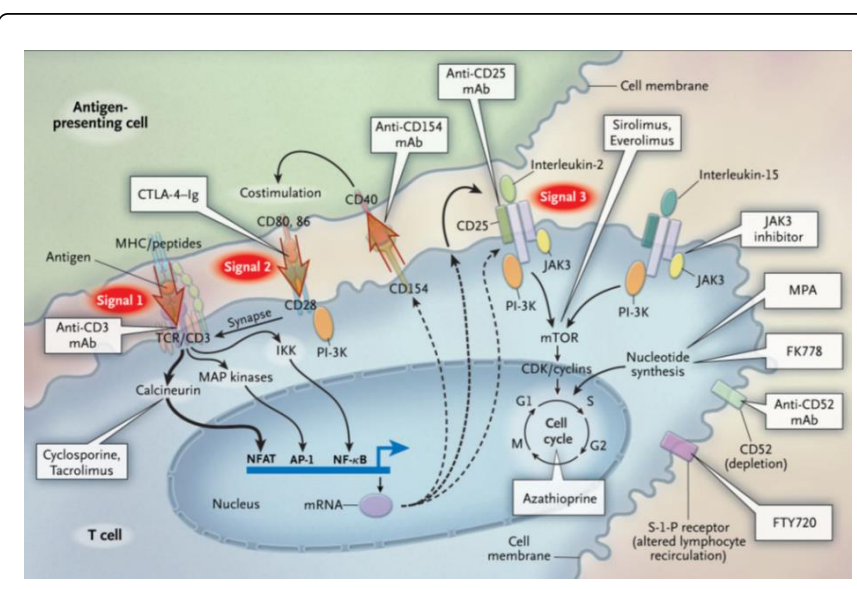

Figure 1: Three signal pathways of T-cell activation [19].

CNIs, including CyA and tacrolimus, work by binding to an intracellular protein (cyclophillin and FK-binding protein, respectively). This action blocks signal 1 of T-cell activation by inhibition of dephosphorylation and translocation of the nuclear factor of activate T-cells (NFAT). CNIs form the cornerstone of immunosuppressants [5,6]. Common side effects and doses are outlined in Table 3 [20]. There are concerns regarding their link to chronic allograft fibrosis and nephropathy [41,42]. CNIs require frequent monitoring of blood levels $[4,43]$ and exhibit interaction with a wide variety of medications, as they are metabolized by liver cytochrome p450 [4]. Tacrolimus-based immunosuppressants were shown to be superior to CyA-based ones in terms of survival and/or acute rejection rate [43-46]. Recent years showed much more use of tacrolimus, while the use of CyA has substantially reduced in Figure 4 [2].

Other maintenance immunosuppressant agents include the antiproliferative group. This includes azathioprine, MMF and its entericcoated formulation, myfotic. Azathioprine has been in use since the early days of transplantation [4]. It is an imidazole derivative of 6mercaptopurine, and is incorporated in DNA to inhibit gene transcription [21]. Table 3 lists doses and side effects. It has been largely superseded by the mycophenolate medications in Figure 5 [2]. Mycophenolate is a reversible inhibitor of inosine monophosphate dehydrogenase (IMPDH), which is the rate-limiting enzyme of purine synthesis. IMPDH is found mainly in lymphocytes thus mycophenolate inhibit proliferation of $\mathrm{T}$ as well as B-lymphocytes [47].

\begin{tabular}{|l|l|l|l|l|}
\hline Generic Name (Brand name) & Depleting/non-depleting & Dosing & Common side effects & Generic Name (Brand name) \\
\hline Basiliximab (Simulect $\left.{ }^{\circledR}\right)$ & Non depleting & $20 \mathrm{mg} \mathrm{IV} \times 2$ doses & $\begin{array}{l}\text { None reported compared to } \\
\text { placebo }\end{array}$ & ${\left.\text { Basiliximab (Simulect }{ }^{\circledR}\right)}$ \\
\hline
\end{tabular}




\begin{tabular}{|c|c|c|c|c|}
\hline $\begin{array}{l}\text { Antithymocyte globulin equine } \\
\left(\text { ATGAM }^{\circledR}\right)\end{array}$ & Depleting & $\begin{array}{l}15 \mathrm{mg} / \mathrm{kg} / \mathrm{day} \text { IV } \times 3-14 \\
\text { days }\end{array}$ & $\begin{array}{l}\text { Flu-like symptoms, GI distress, } \\
\text { rash, back } \\
\text { myelosuppression }\end{array}$ & $\begin{array}{l}\text { Antithymocyte globulin equine } \\
\left(\text { ATGAM }^{\circledR}\right)\end{array}$ \\
\hline $\begin{array}{l}\text { Antithymocyte globulin rabbit } \\
\left(\text { Thymoglobulin }^{\circledR}\right)\end{array}$ & Depleting & $30 \mathrm{mg} \mathrm{IV} \times 1-2$ doses & $\begin{array}{l}\text { Flu-like symptoms, GI distress, } \\
\text { rash, back } \\
\text { myelosuppression }\end{array}$ & $\begin{array}{l}\text { Antithymocyte globulin rabbit } \\
\text { (Thymoglobulin }{ }^{\circledR} \text { ) }\end{array}$ \\
\hline Alemtuzumab (Campath ${ }^{\circledR}$ ) & Depleting & $30 \mathrm{mg} \mathrm{IV} \times 1-2$ doses & $\begin{array}{l}\text { Flu-like symptoms, GI distress, } \\
\text { dizziness, myelosuppression }\end{array}$ & Alemtuzumab (Campath ${ }^{\circledR}$ ) \\
\hline
\end{tabular}

Table 2: Common induction agents in transplantation, doses and side effects. Modified from: Gabadi et al. [20].

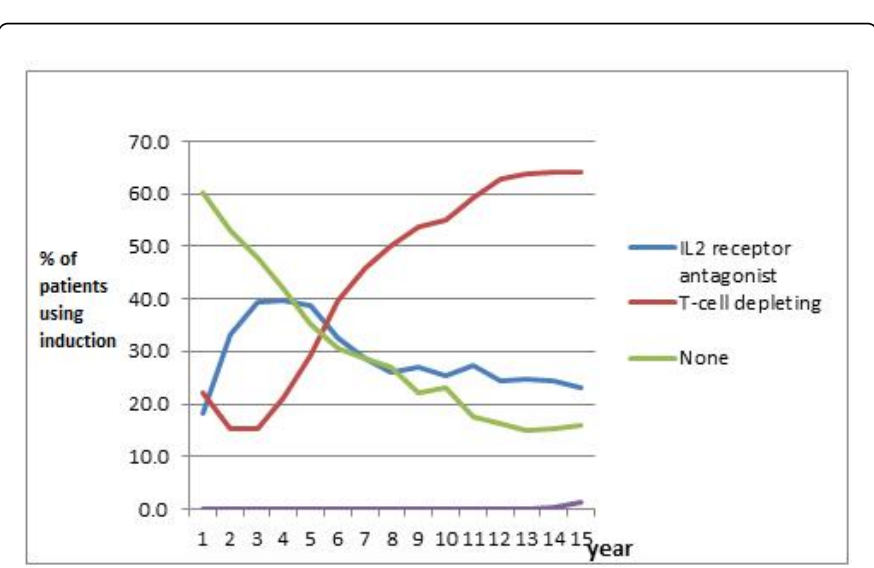

Figure 2: Use of the different induction agents in renal transplantation, data from the OPTN/SRTR $12^{\text {th }}$ annual report. Modified from: OPTN/SRTR, $12^{\text {th }}$ annual report [2].

Maintenance immunosupressive treatment also includes mTOR-I, comprised of sirolimus and evarolimus, binds to FK protein but would not inhibit calcineurin. Their complex with calcineurin binds to rapamycin target and inhibit signal 3 of T-cell activation, through inhibition of cytokines activating T-cell cycle [19].Again they have a lot of drug interactions as they are metabolized by $\mathrm{p} 450$, and interact with CNIs [4]. They have many side effects, including infection [48-55], GI symptoms $[20,49,52,53,56,57]$, poor wound healing $[20,48,51,52,58-60]$, hyperlipidaemia [20,50,52-55,57,58,61-63], deceased sperm count in males on sirolimus [64] and worsening proteinuria $[54,55,57,59,61,62,65,66]$. Data from the OPTN/SRTR showed that their use in kidney transplantation has largely reduced in the recent years see Figure 6 [2].

The use of combination of immunosuppressive agents helps controlling immune response to the graft [20] however, this beneficial effect occurred at the expense of reducing immunity to infection $[20,21]$. Also their use is associated with more liability to malignancy including Kaposi's sarcoma, post-transplant lymphoproliferative disease (PTLD), lung, kidney and prostate cancers [63]. The mTOR-I is associated with reduction of malignancy, mainly non-melanoma skin cancer $[64,67,68]$. Moreover, they are associated with lesser CMV viremia [69], and everolimus was shown to be superior to MMF in that aspect in a pooled analysis of three clinical trials [70]. Additionally, mTOR-I showed favourable effect in BK viremia/BK associated nephropathy $[71,72]$ and post-transplant encapsulating peritoneal sclerosis [73-75].

\section{Immunosuppressive Protocols Using mTOR-I Among Low Risk Renal Transplantation}

Given the side effects of CNIs outlined earlier [20,41,42], and the reduced malignancy risk observed with mTOR-I $[65,67,68]$, several studies looked into their potential use in the context of kidney transplantation. Some studies looked into CNI avoidance with De novo $\mathrm{m}$ TOR-I introduction [45,56,76-82], while others looked into conversion from CNI into mTOR-I at a later stage $[54,63,66,83,84]$ Table 4. Several studies showed that mTOR-I have good effect on preserving kidney function (as noted by changes in eGFR). Moreover, mTOR-I was used in combination with CNI as CNI sparing regiments and their use in combination with low dose CNI showed good graft survival and low rejection rate in Table 4. [48,50-53,57,84-90]. Larson et al. studied mTOR-I while completely avoiding CNI in a prospective randomized trial, comparing sirolimus, MMF and prednisolone (81 patients), to tacrolimus, MMF and prednisolone [84 patients], for an average of 33 months. At one year, patients' survival, graft survival, eGFR and acute rejection were similar in the two groups [58]. Additionally, Oh et al. studied 148 renal transplant recipients for 1 year. Patients were randomized one month after transplantation to receive everolimus, low dose CyA or to have MMF plus standard CyA dose. $\mathrm{AR}$ rate were similar in the two groups, but there was significantly higher eGFR among the everolimus group [91]. In the CONCEPT trial (2009), 192 patients who were on dacluzimab induction, and baseline CyA, MMF and prednisolone (which was withdrawn at 8 months), were studied prospectively. At 3 months post transplantation 95 were randomized to convert to sirolimus and 97 remained on CyA. Patient survival was similar and there was improved eGFR on the sirolimus group. However, the sirolimus group showed non-significantly more acute rejection (17\% vs. $8 \%$ ), and significantly more hyperlipidemia, lower $\mathrm{HB}$, and more proteinuria [60]. Similarly, in the Spare-thenephron trial (2011), the feasibility of mTOR-I use in a CNI-free regiment was studied [62]. In this study, 299 patients who were on initial CNI/MMF protocols were randomized after 30 to 180 days into MMF/ sirolimus (148 patients) and MMF/CNI (151 patients). Patients received variable induction therapy in both arms of the trial, including thymoglobulin, basiliximab, dacluzimab and Muromonab-CD3. At 24 months, patients who were on sirolimus/MMF had significantly higher eGFR compared to those on CyA/MMF. Also the eGFR was nonsignificantly higher among patients who were on sirolimus/MMF compared to tacrolimus/MMF. Patients on the sirolimus/MMF has similar opportunistic infection to the CNI/MMF group, however, they had significantly more dyslipidaemia, oedema, proteinuria and mouth ulcers. There was significantly lower BP among the sirolimus/MMF group compared to the Tacrolimus/MMF one, while hyperglycaemia was non-significantly worse in CNI/MMF group [62]. On the other hand, some studies showed less favourable effects of mTOR-I. 
Citation: Mekki M, Bridson JM, Sharma A, Halawa A (2017) m-TOR Inhibitors in Kidney Transplantation: A Comprehensive Review. J Kidney 3:

Page 5 of 12

\begin{tabular}{|c|c|c|}
\hline Generic name (brand name) & Common oral dosage & Common adverse effects \\
\hline $\begin{array}{l}\text { CyA (Sandimmune }{ }^{\circledR}, \quad \text { Neoral }^{\circledR}, \\
\text { Gengraf }\end{array}$ & $4-5 \mathrm{mg} / \mathrm{kg}$ by mouth twice a day & $\begin{array}{l}\begin{array}{l}\text { Neurotoxicity, gingival hyperplasia, } \\
\text { hyperlipidemia, glucose } \\
\text { abnormalities }\end{array} \\
\text { intolerance, nephrotoxicity, electrolyte } \\
\end{array}$ \\
\hline TAC (Prograf $\left.{ }^{\circledR}\right)$ & $0.05-0.075 \mathrm{mg} / \mathrm{kg}$ by mouth twice a day & $\begin{array}{l}\text { Neurotoxicity, alopecia, hypertension, hyperlipidemia, glucose intolerance, } \\
\text { nephrotoxicity, electrolyte abnormalities }\end{array}$ \\
\hline AZA $\left(\operatorname{Imuran}^{\circledR}\right)$ & $1-2.5 \mathrm{mg} / \mathrm{kg}$ by mouth once a day & Myelosuppression, gastrointestinal disturbances, pancreatitis \\
\hline MMF (CellCept $\left.{ }^{\circledR}\right)$ & $0.5-1.5 \mathrm{~g}$ by mouth twice a day & Myelosuppression, gastrointestinal disturbances \\
\hline EC-MPA (Myfortic ${ }^{\circledR}$ ) & 720 mg by mouth twice a day & Myelosuppression, gastrointestinal disturbances \\
\hline Sirolimus (Rapamune ${ }^{\circledR}$ ) & $1-10 \mathrm{mg}$ by mouth once a day & $\begin{array}{l}\text { Hypertriglyceridemia, myelosuppression, mouth } \\
\text { hypercholesterolemia, gastrointestinal disturbances, impaired } \\
\text { healing, lymphocele, pneumonitis }\end{array}$ \\
\hline Everolimus (Zortress ${ }^{\circledR}$ ) & $0.75 \mathrm{mg}$ by mouth twice a day & $\begin{array}{l}\text { Hypertriglyceridemia, myelosup-pression, mouth } \\
\text { hypercholesterolemia, gastrointestinal disturbances, impaired } \\
\text { healing, lymphocele, pneumonitis }\end{array}$ \\
\hline Belatacept (Nulojix ${ }^{\circledR}$ ) & $\begin{array}{l}10 \mathrm{mg} / \mathrm{kg} / \mathrm{dose} \text { IV on post-op days } 1 \text { and } 5 \text { and at the } \\
\text { end of post-op weeks } 2,4,8 \text { and } 12.5 \mathrm{mg} / \mathrm{kg} / \mathrm{dose} \\
\text { given every } 4 \text { weeks starting at the end of post-op } \\
\text { week } 16 .\end{array}$ & $\begin{array}{l}\text { Anaemia, leukopenia, peripheral oedema, gastrointestinal disturbances, } \\
\text { headache }\end{array}$ \\
\hline Prednisone (Deltasone ${ }^{\circledR}$ ) & Maintenance: $2.5-20 \mathrm{mg}$ by mouth once a day & $\begin{array}{l}\text { Mood disturbances, psychosis, cataracts, hypertension, fluid retention, } \\
\text { peptic ulcers, osteoporosis, muscle weakness, impaired wound healing, } \\
\text { glucose intolerance, weight gain, hyperlipidaemia }\end{array}$ \\
\hline
\end{tabular}

Table 3: Common maintenance immunosuppressant, doses and side effects.

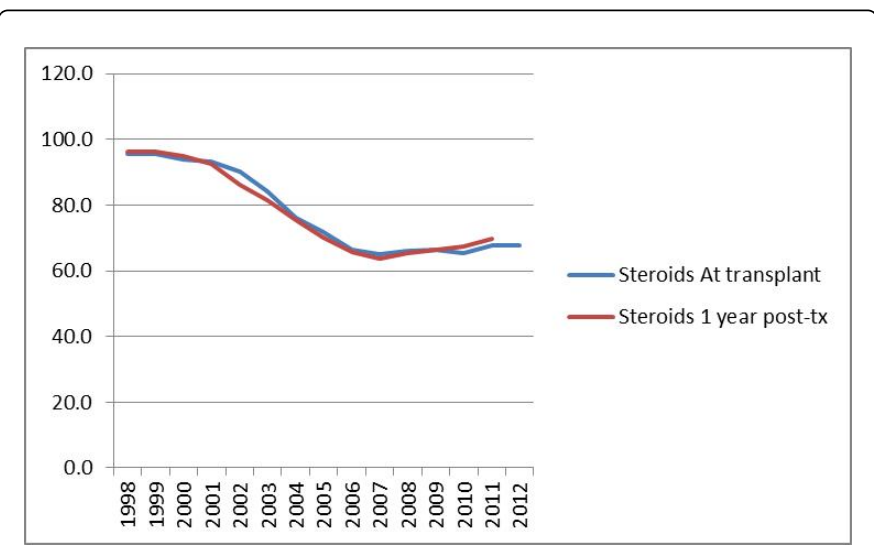

Figure 3: Use of steroid, data from the OPTN/SRTR $12^{\text {th }}$ annual report. Modified from: OPTN/SRTR, $12^{\text {th }}$ annual report [2].

In the ORION study (2011), Flechner et al. studied 3 treatment groups: sirolimus plus tacrolimus (tacrolimus withdrawal after 13 months, $\mathrm{n}=152$ patients), sirolimus plus MMF ( $\mathrm{n}=152$ patients) and tacrolimus+MMF (139 patients). There was more biopsy-proven rejection among the sirolimus/MMF group leading to discontinuation of that arm. There was more rejection in the sirolimus group; however, graft survival was similar in the remaining two groups [59]. Less favourable results were also shown in a 36 months prospective randomized controlled study which was conducted in 11 centers from

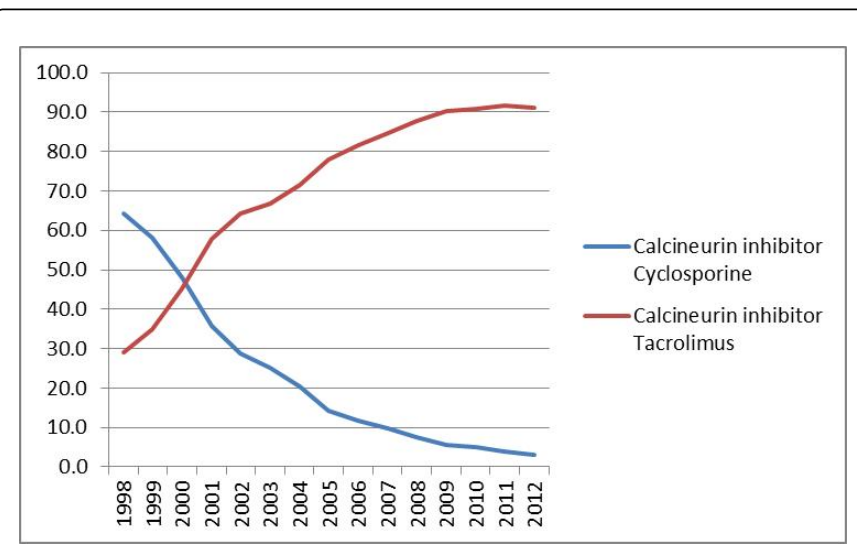

Figure 4: Use of CNI, data from the OPTN/SRTR $12^{\text {th }}$ annual report. Modified from: OPTN/SRTR, $12^{\text {th }}$ annual report [2].

Australia, New Zealand, Taiwan, Malaysia, and Korea: The SCORATES study (2014). In this study, 126 patients on CyA, MMF, steroids and basiliximab for induction were randomized 14 days after transplantation into three groups to eliminate MMF plus either CNI or steroids. Group 1 ( $n=45)$ : The CNI withdrawal group (CNI-WD), CNI plus MMF were withdrawn and continued on everolimus plus steroids; group $2(\mathrm{n}=40)$ : The steroid withdrawal group (steroid-WD) in which MMF and steroids were withdrawn, and they continued on everolimus plus CNI; and group $3(\mathrm{n}=22)$ : The control group with CNI, MMF and steroids. 


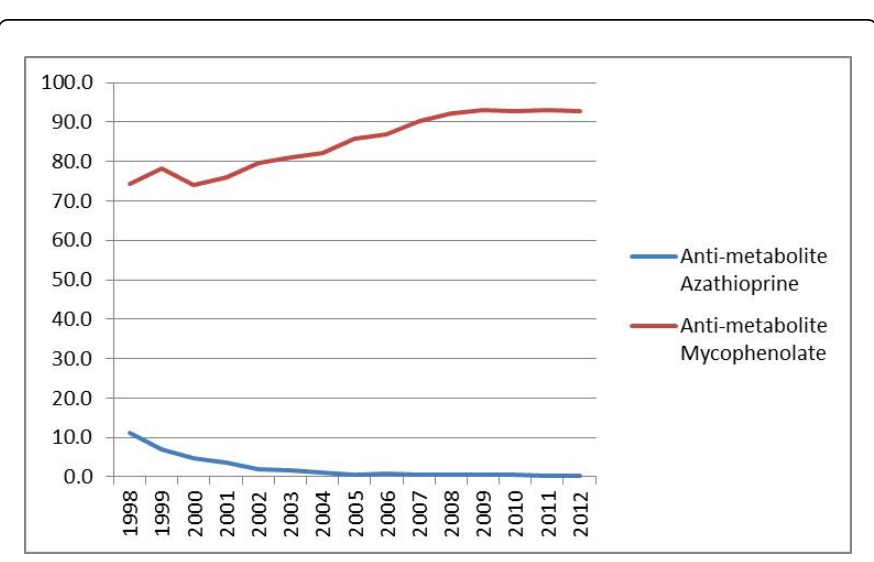

Figure 5: Use of antimetabolites, data from the OPTN/SRTR $12^{\text {th }}$ annual report. Modified from: OPTN/SRTR, $12^{\text {th }}$ annual report [2].

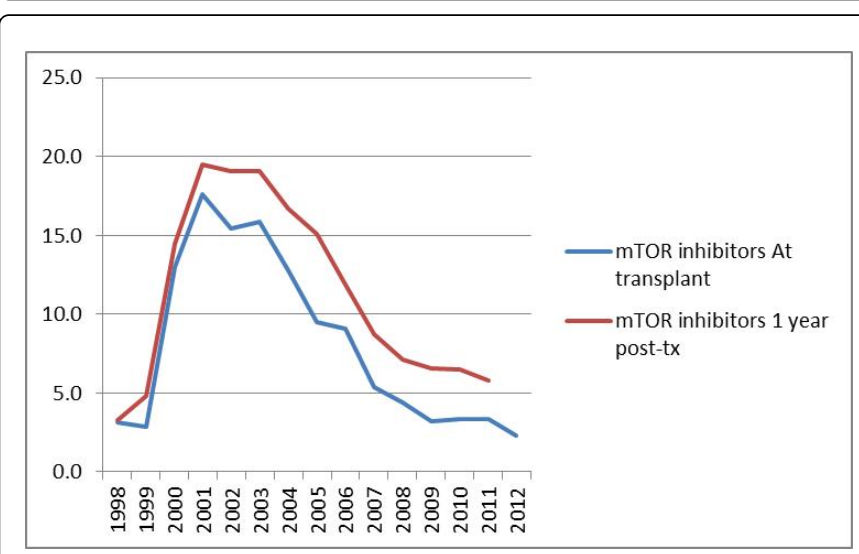

Figure 6: Use of mTOR, data from the OPTN/SRTR $12^{\text {th }}$ annual report. Modified from: OPTN/SRTR, $12^{\text {th }}$ annual report [2].

The steroid-WD was discontinued prematurely as there was high rate of discontinuation. At 12 months, in the everolimus group, the eGFR was non-inferior; however there was significantly more rejection and a trend towards more graft and patient loss [56]. Also, in the ELITE Symphony study (2007), 1645 patients were treated with standard CyA, MMF and steroids; low dose tacrolimus with dacluzimab in the first 2 months; low dose CyA and MMF; and low dose sirolimus with dacluzimab for two months. The patients were followed for one year: the low dose tacrolimus showed significantly higher eGFR, less rejection and better graft survival compared to all other groups [49].

A systematic review and meta-analysis included 2067, studied patients who were on everolimus with CNI minimization or elimination, compared to standard CNI protocols. Patients on everolimus plus CNI elimination have significantly more rejection, without increasing patient mortality or graft loss, and a better eGFR compared to the standard CNI protocols. However patients on everolimus with CNI minimization had similar graft rejection compared to the control CNI protocols [92]. An earlier systematic review and meta-analysis (2006) showed that when mTOR-I replaced CNI (750 patients), there would be same rejection rate, lower creatinine and more marrow suppression; when replaced antimetabolites (3966 patients) there was less rejection and lower CMV infection but higher hyperlipidaemia. However when mTOR-I used in combination with CNI (3175 patients) graft and patient survival were similar in all comparison groups (low dose mTOR-I vs. High dose mTOR inhibitors in combination with standard CNI doses, and variable mTOR-I inhibitors doses with variable CNI doses). Patients on low dose mTOR-I had more rejection and better eGFR compared to the high dose with similar CNI doses. Similar results with the low dose mTOR-I plus standard dose CNI compared to the high dose mTOR-I plus low CNI dose [93].

Other studies from Table 4, looked into various mTOR-I based protocols with results comparable to the above-discussed studies. Overall, it appears that there is good evidence of the efficacy of mTORI in preserving the transplanted kidney function, with a graft survival comparable to other conventional immunosuppressant protocols, among standard risk renal transplant recipients.

\section{High-Risk Renal Transplantation \& Extended-Criteria Renal Transplants and mTOR-I Protocols}

Compared to low risk renal transplantation, mTOR-I are less studied among other risk groups. Few studies showed that mTOR-I have good and comparable results to other standard protocols among recipients of extended-criteria donors [92-98]. Even fewer studies looked in their use among high-risk renal transplant recipients. Sirolimus containing regiments, with $\mathrm{CyA}$ and prednisolone, were shown to have equal efficacy and graft survival to CyA, azathioprine and prednisolone regiments, among renal transplant recipients at high risk of delayed graft function $[99,100]$. Uchida et al. studied 16 stable $\mathrm{ABO}$ incompatible renal transplant recipients who were on MMF and standard CNI. MMF was substituted by everolimus with low dose CNI, and there was no increased rejection at three months [101]. Other earlier studies showed also good results on mTOR-I among high immunologic risk renal transplants $[101,102]$. However, Lee et al. reported an unfavourable outcome in a pilot study of 28 sirolimusbased high-risk renal transplant recipient compared to 69 control patients on MMF, CNI and prednisolone. There was non-significantly higher rejection rate, lower survival and lower eGFR among the sirolimus-treated group. Also there were increased side effects on the sirolimus group [103].

\section{Other Aspects of mTOR-I Protocols in Kidney Transplantation}

Looking into other aspects related to the use of mTOR-I, sirolimus was shown to be cost effective. The cost of treatment and graft loss were compared among 4 groups: early sirolimus+withdrawal of steroids/CNI, early transition by sirolimus, early transition by everolimus, and the standard prednisolone, MMF and CNI. The lowest cost was for early sirolimus transition group [104].

\section{Safety of mTOR-I Protocols in Kidney Transplantation}

Taking into consideration all what is discussed above, safety might be an issue. A recent systematic review and meta-analysis of 21 RCT studies included 5876 patients, was conducted by Knoll et al. It was demonstrated that mTOR-I use, although associated with a $40 \%$ reduction of malignancy and $56 \%$ reduction of non-melanoma skin cancer, was associated with an increased risk of mortality [105]. 
Citation: Mekki M, Bridson JM, Sharma A, Halawa A (2017) m-TOR Inhibitors in Kidney Transplantation: A Comprehensive Review. J Kidney 3:

Page 7 of 12

\begin{tabular}{|c|c|c|c|c|c|}
\hline $\begin{array}{l}\text { Author, year/Study } \\
\text { design/ (reference) }\end{array}$ & $\begin{array}{l}\text { Number } \\
\text { patients }\end{array}$ & $\begin{array}{l}\text { mTOR-I use De novol } \\
\text { conversion/CNI sparing }\end{array}$ & Comparison group & Acute rejection & eGFR \\
\hline $\begin{array}{l}\text { Gatault et al. SPIESSER } \\
\text { study; Open label } \\
\text { comparative randomized } \\
\text { study, } 8 \text { years follow-up } \\
{[77]}\end{array}$ & 99 & De novo & $\begin{array}{l}\text { SRL+MMF vs. } \quad \text { CyA+MMF } \\
\text { Thymoglobulin (Ind), steroid (withd) at } \\
5 / 12\end{array}$ & - & $\uparrow$ in SRL \\
\hline $\begin{array}{l}\text { Uchida et al, 2016 } \\
\text { Retrospective pilot [63] }\end{array}$ & 26 & Conversion & $\begin{array}{l}\text { Antimetabolite+CNI vs. } \quad \mathrm{EVR}+\mathrm{CNI} \\
\text { (min.) }\end{array}$ & -- & 个in EVR \\
\hline $\begin{array}{l}\text { Yoshimura et al. } \\
\text { Prospective study. [87] }\end{array}$ & 29 & 29 & $\begin{array}{l}\text { EVR+(LD) Tac+MZR+ pred vs. no EVR. } \\
\text { basiliximab (Ind) }\end{array}$ & Similar & Similar \\
\hline $\begin{array}{lrr}\text { Yamanaka } & \text { et } & \text { al. } \\
\text { Retrospective study } & {[86]}\end{array}$ & 12 & $\mathrm{CNI}$ sparing & EVR+(LD) Tac+MMF+pred vs. no EVR & $\begin{array}{l}\uparrow \text { in EVR (Sub- } \\
\text { clinical) }\end{array}$ & $\uparrow$ in EVR \\
\hline 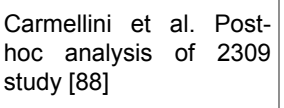 & 833 & De novo & $\begin{array}{l}\text { EVR+(LD) CyA vs. MMF+CyA. } \\
\text { Basiliximab (Ind) }\end{array}$ & Similar & -- \\
\hline $\begin{array}{l}\text { Mühlbacher et al. Open } \\
\text { label, multi-centre [50] }\end{array}$ & 420 & $\mathrm{CNI}$ sparing & $\begin{array}{l}\text { SRL+pred+(LD) CyA vs. SRL+pred+ } \\
\text { (Sd) CyA }\end{array}$ & Similar & $\uparrow$ in (LD) CyA \\
\hline $\begin{array}{l}\text { Huang et al. Prospective } \\
\text { open label [89] }\end{array}$ & 112 & 112 & $\mathrm{SRL}+\mathrm{MMF}+$ Pred $v s . \mathrm{CNI}+\mathrm{MMF}+$ Pred & Similar & $\uparrow$ in SRL \\
\hline $\begin{array}{l}\text { Bechstein et } \quad \text { al. } \\
\text { Prospective open label } \\
\text { multi-centre randomized } \\
\text { [51] }\end{array}$ & 128 & $\mathrm{CNI}$ sparing & $\begin{array}{l}\text { SRL+(LD) Tac+Pred vs. SRL+(Sd)Tac } \\
\text { +pred }\end{array}$ & Similar & $\uparrow$ in (LD) Tac \\
\hline $\begin{array}{llr}\text { Lebranchu } & \text { et } & \text { al. } \\
\text { Retrospective } & \text { follow-up } \\
\text { of SPIESSER study [55] }\end{array}$ & 131 & De novo & SRL+MMF vs. CyA+MMF & Similar & $\uparrow$ in SRL \\
\hline $\begin{array}{l}\text { Langer et al. ASSETT } \\
\text { study. A phase } 111 \\
\text { Open label prospective } \\
\text { randomized multicenter } \\
{[59]}\end{array}$ & 228 & $\mathrm{CNI}$ sparing & $\begin{array}{l}\text { EVR+(LD) Tac+pred vs. EVR+(Sd) Tac } \\
\text { +Pred. Basiliximab+steroids (Ind) }\end{array}$ & Similar & Similar \\
\hline $\begin{array}{l}\text { Budde et al. ZEUS } \\
\text { study, Open Label multi- } \\
\text { centre study [66]. }\end{array}$ & 300 & Conversion & $\begin{array}{l}\text { CyA+Pred+Myfortic vs. +EVR+Pred } \\
\text { +Myfortic. Basliximab (Ind) }\end{array}$ & $\uparrow$ in EVR & $\uparrow$ in EVR \\
\hline $\begin{array}{l}\text { Paoletti et al. Case } \\
\text { control study [83]. }\end{array}$ & 39 & Basliximab (Ind) & SRL+MMF vs. CyA+MMF & Similar & $\uparrow$ in SRL \\
\hline $\begin{array}{l}\text { Han et al. Prospective } \\
\text { randomized open label } \\
\text { study [84]. }\end{array}$ & 51 & Conversion & CyA+MMF+Pred vs. SRL+MMF+Pred & - & $\uparrow$ in SRL \\
\hline $\begin{array}{l}\text { Bertoni et al. } \\
\begin{array}{l}\text { Randomized } \\
\text { single- } \\
\text { centre open-labelled } \\
\text { prospective }[76]\end{array}\end{array}$ & 106 & $\mathrm{CNI}$ sparing & $\mathrm{EVR}+(\mathrm{LD}) \mathrm{CyA}$ vs. CyA+MMF & -- & $\uparrow$ in EVR \\
\hline $\begin{array}{l}\text { Holdaas } \\
\begin{array}{l}\text { ASCERTAIN } \\
\text { investigator, }\end{array} \\
\text { labelled } \\
\text { multicenter study } \\
\text { manizen } \\
\end{array}$ & 404 & $\mathrm{CNI}$ sparing & $\begin{array}{l}\text { EVR+CNI (Withd) vs. EVR+CNI (Min.) } \\
\text { vs. CNI based control }\end{array}$ & $\uparrow$ in CNI (Withd) & $\uparrow$ in CNI (Withd) \\
\hline $\begin{array}{l}\text { Schena et al. CONVERT } \\
\text { Trial, Open label } \\
\text { prospective comparative } \\
{[54]}\end{array}$ & 830 & Conversion & $\begin{array}{l}\text { CNI+Pred+either MMF or Aza vs. SRL } \\
\text { +Pred+either MMF or Aza }\end{array}$ & -- & $\uparrow$ in SRL \\
\hline $\begin{array}{l}\text { Tsai et al. Retrospective } \\
\text { cohort [85] }\end{array}$ & 206 & $\mathrm{CNI}$ sparing & (LD) CNI+SRL vs. (Sd) CNI+MMF & $\downarrow$ in SRL & -- \\
\hline
\end{tabular}


Citation: Mekki M, Bridson JM, Sharma A, Halawa A (2017) m-TOR Inhibitors in Kidney Transplantation: A Comprehensive Review. J Kidney 3:

Page 8 of 12

\begin{tabular}{|c|c|c|c|c|c|}
\hline 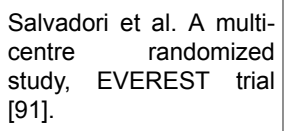 & 285 & CNI sparing & $\begin{array}{l}\text { (LD) EVR+(HD) CyA vs. (HD) EVR+ } \\
\text { (LD) CyA }\end{array}$ & Similar & Similar \\
\hline $\begin{array}{l}\text { Albano et al. } 2009 \text {. } \\
\text { Prospective multi-centre } \\
\text { open label randomized } \\
\text { trial. [48] }\end{array}$ & 139 & CNI sparing & $\begin{array}{llr}\text { EVR+CyA+Pred vs. } & \text { EVR } & \text { (MMF } \\
\text { conversion)+CyA+Pred. } & \text { IL2 } & \text { blocker } \\
\text { (Ind) } & & \end{array}$ & Similar & Similar \\
\hline $\begin{array}{l}\text { Chan et al. Randomized } \\
\text { open label prospective } \\
\text { multi-centre [52] }\end{array}$ & 92 & CNI sparing & $\begin{array}{l}\text { EVR+pred+(LD) Tac vs. EVR+(Sd) Tac } \\
+ \text { +Pred. Basiliximab+steroids (Ind) }\end{array}$ & Similar & Similar \\
\hline $\begin{array}{l}\text { Kumar et al. Prospective } \\
\text { randomized pilot study } \\
{[45]}\end{array}$ & 200 & De novo & $\begin{array}{l}\text { CyA+MMF vs. CyA+SRL vs. Tac+MMF } \\
\text { vs. Tac+SRL. Basiliximab+steroid (Ind). } \\
\text { Early steroid (Withd) }\end{array}$ & $\begin{array}{l}\text { \in Tac+MMF, Tac } \\
+S R L, C s A+S R L\end{array}$ & Similar \\
\hline $\begin{array}{l}\text { Carmellini et al. Single- } \\
\text { centre } \quad \text { retrospective. } \\
{[77]}\end{array}$ & 286 & CNI sparing & $\begin{array}{l}\text { mTOR+(LD) CNI+pred vs. (HD) CNI } \\
\text { +MMF+Pred. Basiliximab (Ind) }\end{array}$ & Similar & -- \\
\hline $\begin{array}{l}\text { Flechner et al. } \\
\text { Randomized } \\
\text { prospective [80]. }\end{array}$ & 61 & De novo & $\begin{array}{l}\mathrm{SRL}+\mathrm{MMF}+\text { Pred } v s . \quad \mathrm{CNI}+\mathrm{MMF}+\text { Pred. } \\
\text { Basiliximab (Ind) }\end{array}$ & -- & $\uparrow$ in SRL \\
\hline Diekmann et al. [79]. & 108 & De novo & $\begin{array}{l}\text { SRL+MMF+pred+anti CD } 25 \text { (Ind) vs. } \\
\text { pred+MMF +/- anti CD } 25\end{array}$ & $\uparrow$ in MMF & -- \\
\hline $\begin{array}{l}\text { Kandaswamy et al. } \\
\text { Prospective randomized } \\
{[90] .}\end{array}$ & 239 & CNI sparing & $\begin{array}{l}\text { CsA+MMF vs. (HD) Tac+(LD) SRL vs. } \\
\text { (LD) Tac+(HD) } \\
\text { (Ind) }\end{array}$ & Similar & Similar \\
\hline $\begin{array}{l}\text { Flechner et al. } \\
\text { Prospective randomized } \\
\text { [80] }\end{array}$ & 58 & De novo & $\begin{array}{l}\mathrm{SRL}+\mathrm{MMF}+\text { Pred vs. CyA+MMF+Pred. } \\
\text { Basiliximab (Ind) }\end{array}$ & -- & $\uparrow$ in SRL \\
\hline $\begin{array}{l}\text { Kreis et al. Open label } \\
\text { multi-centre study [81] }\end{array}$ & 78 & De novo & SRL+MMF+Pred $v s . C y A+M M F+$ Pred & Similar & $\uparrow$ in SRL \\
\hline
\end{tabular}

Table 4: mTOR-I based protocols[46,48,51-53,55,57,63,65,75,77-79,81-89,91,92]

\begin{tabular}{|c|c|c|c|c|}
\hline Author (reference) & Year & $\begin{array}{l}\text { No of patients on } \\
\text { mTOR/overall No of } \\
\text { patients }\end{array}$ & $\begin{array}{l}\text { Discontinuation } \\
(\%)\end{array}$ & Reported side effects \\
\hline Gatault et al. [78] & 2016 & $50 / 99$ & 48 & -- \\
\hline Uchida et al. [64] & 2016 & $26 / 26$ & 42.3 & $\begin{array}{l}\text { Hypercholesterolemia, oedema, aphthous ulcers, fatigue, } \\
\text { anaemia, menoxemia, interstitial pneumonitis, acne }\end{array}$ \\
\hline Lee et al. [94] & 2015 & $28 / 97$ & 28.6 & Higher hyperlipidemia, BK virus and lymphocele. \\
\hline Chadban et al. [56] & 2014 & $15 / 54$ & 31 & Diarrhoea \\
\hline Mühlbacher et al. [50] & 2014 & $101 / 420$ & 24 & $\begin{array}{l}\text { Infections (UTIs/pyelonephritis, pneumonia, CMV, wound), } \\
\text { lymphocele, oedema, hyperlipidaemia, anaemia, raised } \\
\text { creatinine, HTN }\end{array}$ \\
\hline Bechstein et al. [51] & 2013 & $128 / 128$ & 25.8 & $\begin{array}{l}\text { Infections (wound, UTI, candida, sepsis, CMV, Herpes } \\
\text { simplex, Herpes zoster, pneumonia), lymphocele, wound } \\
\text { dehiscence }\end{array}$ \\
\hline Langer et al. [57] & 2012 & $228 / 228$ & 13.6 & $\begin{array}{l}\text { Hyperlipidaemia, hyperglycaemia, hypo and hyperkalaemia, } \\
\text { GI disturbance, oedema, HTN, lymphocele, anaemia, } \\
\text { insomnia, acne, proteinuria }\end{array}$ \\
\hline Budde et al. (66) & 2012 & $138 / 269$ & 28.4 & Aphthous ulcers, proteinuria, anaemia \\
\hline Euvrard et al. [67] & 2012 & $64 / 120$ & 23 & Aphtous ulcers, oedema, pneumonitis, rash \\
\hline
\end{tabular}


Citation: Mekki M, Bridson JM, Sharma A, Halawa A (2017) m-TOR Inhibitors in Kidney Transplantation: A Comprehensive Review. J Kidney 3:

\begin{tabular}{|c|c|c|c|c|}
\hline Campbell et al. [65] & 2012 & $39 / 87$ & 42.6 & $\begin{array}{l}\text { Pneumonitis, diarrhoea, decreased tolerance, rash, mouth } \\
\text { ulcers, proteinuria, epistaxis }\end{array}$ \\
\hline Burkhalter et al. [95] & 2012 & $65 / 65$ & 25 & Leukopenia, anaemia, arthritis, and pneumonitis \\
\hline Lebranchu et al. [55] & 2012 & $63 / 131$ & 33 & $\begin{array}{l}\text { Proteinuria, pneumonia, hyperlipidaemia, hyperglycaemia, } \\
\text { oedema, mouth ulcers, pyelonephritis }\end{array}$ \\
\hline Holdaas et al. [53] & 2011 & $281 / 404$ & $\begin{array}{ll}28.3 \text { in } & \mathrm{CNI} \\
\text { elimination } & \text { and } \\
16.7 \text { in } & \mathrm{CNI} \\
\text { minimization } & \end{array}$ & $\begin{array}{l}\text { Rash, mouth ulcers, oedema, hyperlipidaemia, anaemia, } \\
\text { diarrhoea infection, acne }\end{array}$ \\
\hline Weir et al. [62] & 2011 & $148 / 299$ & 19 & $\begin{array}{l}\text { Hyperlipidaemia, peripheral oedema, mouth ulcers, } \\
\text { proteinuria }\end{array}$ \\
\hline Flechner et al. [59] & 2011 & $304 / 443$ & $33.6-34.2$ & $\begin{array}{l}\text { Pneumonia, Thrombocytopenia, ATN, UTI, oedema, } \\
\text { anaemia, delayed wound healing, lymphoedema }\end{array}$ \\
\hline Tedesco Silva et al. [49] & 2010 & $277 / 833$ and $279 / 833$ & $30-34.1$ & Wound healing, mouth ulcers \\
\hline Schena et al. (54) & 2009 & $555 / 830$ & 25.8 & $\begin{array}{l}\begin{array}{l}\text { Pneumonitis, infection, acne, } \\
\text { hyperlipidaemia, ophous } \\
\text { thrombocytopenia }\end{array}\end{array}$ \\
\hline Albano et al. [48] & 2009 & 139/139 & $20 \& 23$ & Delayed wound healing, infections \\
\hline Lebranchu et al. [55] & 2009 & $95 / 192$ & 16 & Aphthous ulcers, diarrhoea, acne, hypertriglyceridemia \\
\hline Chan et al. [52] & 2008 & $92 / 92$ & 9.8 & $\begin{array}{l}\text { Hyperlipidaemia, oedema, ATN/AKI, renal vein thrombosis, } \\
\text { effusions, wound drainage, anaemia, leucopoenia, } \\
\text { thrombocytopenia, infections (UTI, wound, pneumonia), GI } \\
\text { disturbance }\end{array}$ \\
\hline Ekberg et al. [49] & 2007 & 401/ 1645 & 53.2 & $\begin{array}{l}\text { GI disturbance, Infections, DM, hyperglycemia, } \\
\text { hyperlipidemia, hypercholestrolemia, hypertriglyceridemia, } \\
\text { Hypophosphatemia }\end{array}$ \\
\hline Larson et al. [58] & 2006 & $81 / 165$ & 36 & $\begin{array}{l}\text { Poor wound healing, pulmonary complications, sever } \\
\text { hypertriglyceridemia, thrombocytopenia, acute rejection }\end{array}$ \\
\hline
\end{tabular}

Table 5: Discontinuation rate of mTOR inhibitors and the reported side effects $[49,50-64,66-68,70,81,86]$.

Coupled with it are the frequent adverse reactions necessitating discontinuation of their use. Many studies have showed their high discontinuation/withdrawal rate among patients on mTOR-I reaching up to $53.2 \%$. Proteinuria, primary glomulonephritis, and poor graft function were associated risk factors for withdrawal of mTOR-I, as shown in a recent report on 77 renal transplant recipients in Taiwan [106]. Also, GI symptoms were frequently described among mTOR-I users (Table 5). The presence and severity of GI side effects, among transplant recipients, appear to be associated with lower quality of life [107]. These had often been underestimated by the treating clinicians as shown in a survey conducted by Ekberg et al. [108,109]. Table 5 summarizes the discontinuation rate among patients treated with mTOR-I, together with the commonly encountered side effects. Various studies were examined for discontinuation of mTOR-I secondary to side effect. Included are studies in which all patients received $\mathrm{mTOR}-\mathrm{I}$, and other studies involving additional/comparative treatment agent (as expressed as number of patients on mTOR-I/ overall number of patients). High discontinuation rate was shown throughout most of the different studies conducted in the last decade.

\section{Limitation of the Study}

An important limitation of this study is that the majority of the studies had a short follow-up of 12 months or less. Few numbers of studies examined the effect of mTOR-I at 2-3 years and only two studies looked at a longer term follow-up at 5 and 8 years respectively. Longer term efficacy and safety of mTOR-I in kidney transplantation is still poorly understood.

\section{Conclusion}

Immunosuppressive protocols containing mTOR-I are generally effective in low risk renal transplantation, with a comparable graft survival and a better eGFR, compared to conventional protocols. However, we have limited reports on their efficacy in high-risk groups. They are of particular interest in specific groups of patients including those with malignancies, encapsulating peritoneal sclerosis, BK and CMV virus infections. They were shown to have unacceptable side effect profile leading to high discontinuation rate. These might have contributed to their reduced popularity (both as early and maintenance) in the recent years. Moreover there is a new concern linking their use to increased patients' mortality. More studies, looking into the safety of mTOR-I, are needed.

\section{References}

1. Hariharan S, Johnson CP, Bresnahan BA, Taranto SE, McIntosh MJ, et al. (2000) Improved graft survival after renal transplantation in the United States, 1988 to 1996. N Engl J Med 342: 605-612. 
2. Organ Procurement and Transplantation Network (2017) Department of Health \& Human Services, USA.

3. Fronek J, MacPhee I (2012) History of transplantation. In: Handbook of renal and pancreas transplantation. Wiley-Blackwell, Chichester,UK. pp $1-8$.

4. Thomas G, Nurko S, Srinivas TR (2011) Immunosuppressive therapy in kidney and pancreas transplantation. Kidney and Pancreas transplantation, a practical guide. Pp. 49-86.

5. Ota K, Takahashi K, Toma H (1988) CyA-treated kidney transplants from living-related donors-A single center trial. Clin Transpl pp.189-198.

6. Lewis RM (1995) Long-term use of CyA A does not adversely impact on clinical outcomes following renal transplantation. Kidney Int Suppl 52: S75-S78.

7. Kriesche HUM, Li S, Gruessner RWG, Fung JJ, Bustami RT, et al. (2006) Immunosuppression: Evolution in practice and trends, 1994-2004. Am J Transplant 6: 1111-1131.

8. Pollard SG, Lear PA, Ready AR, Moore RH, Johnson RW (1999) Comparison of microemulsion and conventional formulations of CyA A in preventing acute rejection in de novo kidney transplant patients. The U.K. Neoral Renal Study Group. Transplantation 68: 1325-1331

9. Nezhad AK, Sagheb MM, Amirmoezi F, Jowkar Z, Dehghanian AR (2015) Comparison of the effect of alemtuzumab versus standard immune induction on early kidney allograft function in shiraz transplant center. Int J Organ Transplant Med 6: 150-156.

10. Gupta M, Wood A, Mitra N, Furth SL, Abt PL, et al. (2015) Repeat kidney transplantation after failed first transplant in childhood: Past Performance informs future performance. Transplantation 99: 1700-1708.

11. Ingsathit A, Kantachuvesiri S, Rattanasiri S, Avihingsanon $\mathrm{Y}$, Premasathian N, et al. (2013) Long-term outcome of kidney retransplantation in comparison with first kidney transplantation: A report from the Thai Transplantation Registry. Transplant Proc 45: 1427-1430.

12. MacDonald AS, Belitsky P, Seurmann HB, Cohen A, Gorelick M, et al. (1989) ABO-incompatible living related donor kidney transplantation: Report of two cases. Transplant Proc 21: 3362-3363.

13. Tanabe K, Takahashi K, Sonda K, Tokumoto T, Ishikawa N, et al. (1998) Long-term results of ABO-incompatible living kidney transplantation: A single-center experience. Transplantation 65: 224-228.

14. Yokoyama T, Konno O, Kihara Y, Nakamura Y, Iwamoto H, et al. (2016) Clinical outcomes and results of pathological findings of 1-year protocol biopsy in recipients of abo-incompatible living donor kidney transplantants. Transplant Proc 48: 831-835.

15. Shin E, Kwon SW, Yang WS, Baeck C, Yu H, et al. (2015) Long-term outcomes of abo-incompatible living donor kidney transplantation: A comparative analysis. Transplant Proc. 47: 1720-1726.

16. Carroll R, Coates PT (2015) Does rituximab help in HLA desensitization for kidney transplantation? Kidney Int 87: 277-279.

17. Graff RJ, Xiao H, Duffy B, Schnitzler MA, Axelrod D, et al. (2012) Transplantation with positive complement-dependent microcytotoxicity crossmatch in contemporary kidney transplantation: Practice patterns and associated outcomes. Saudi J Kidney Dis Transpl 23: 234-245.

18. Opelz G (1994) Effect of the maintenance immunosuppressive drug regimen on kidney transplant outcome. Transplantation 58: 443-446.

19. Halloran PF (2004) Immunosuppressive drugs for kidney transplantation. N Engl J Med 351: 2715-2729.

20. Gabardi S, Tichy EM (2011) Overview of immunosuppressive therapies in renal transplantation. Core concepts renal transplant pp. 97-127.

21. Brennan DC, Daller JA, Lake KD, Cibrik D, Castillo DD (2006) Rabbit antithymocyte globulin versus basiliximab in renal transplantation. $\mathrm{N}$ Engl J Med 355: 1967-1977.

22. Chapman TM, Keating GM (2003) Basiliximab: a review of its use as induction therapy in renal transplantation. Drugs 63: 2803-2835.

23. Kahan BD, Rajagopalan PR, Hall M (1999) Reduction of the occurrence of acute cellular rejection among renal allograft recipients treated with basiliximab, a chimeric anti-interleukin-2-receptor monoclonal antibody. United States simulect renal study group. Transplantation 67: 276-284.

24. Berard NB, Vincent C, Revillard JP (1991) Antibodies against functional leukocyte surface molecules in polyclonal antilymphocyte and antithymocyte globulins. Transplant 51: 669-673.

25. Zand MS, Vo T, Huggins J, Felgar R, Liesveld J, et al. (2005) Polyclonal rabbit antithymocyte globulin triggers B-cell and plasma cell apoptosis by multiple pathways. Transplantation 79: 1507-1515.

26. Gaber AO, First MR, Tesi RJ, Gaston RS, Mendez R, et al. (1998) Results of the double-blind, randomized, multicenter, phase III clinical trial of Thymoglobulin versus Atgam in the treatment of acute graft rejection episodes after renal transplantation. Transplantation 66: 29-37.

27. Guttmann RD, Caudrelier P, Alberici G, Touraine JL (1997) Pharmacokinetics, foreign protein immune response, cytokine release, and lymphocyte subsets in patients receiving thymoglobulin and immunosuppression. Transplant Proc 29: 24-26.

28. Clesca P, Dirlando M, Park SI, García R, Ferraz E, et al. (2007) Thymoglobulin and rate of infectious complications after transplantation. Transplant Proc 39: 463-464.

29. Opelz G, Döhler B (2004) Lymphomas after solid organ transplantation: A collaborative transplant study report. Am J Transplant 4: 222-230.

30. Opelz G, Naujokat C, Daniel V, Terness P, Döhler B (2006) Disassociation between risk of graft loss and risk of non-Hodgkin lymphoma with induction agents in renal transplant recipients. Transplantation 81: 1227-1233.

31. Desvergnes GC, Salama A, Berre LL, Evanno G, Viklicky O, et al. (2015) Rabbit antithymocyte globulin-induced serum sickness disease and human kidney graft survival. J Clin Invest 125: 4655-4665.

32. Morgan RD, O'Callaghan JM, Knight SR, Morris PJ (2012) Alemtuzumab induction therapy in kidney transplantation: a systematic review and meta-analysis. Transplantation 93: 1179-1188.

33. Kirk AD, Hale DA, Mannon RB, Kleiner DE, Hoffmann SC, et al. (2003) Results from a human renal allograft tolerance trial evaluating the humanized CD52-specific monoclonal antibody alemtuzumab (CAMPATH-1H). Transplantation 76: 120-129.

34. Umber A, Killackey M, Paramesh A, Liu Y, Qin H, et al. (2017) A comparison of three induction therapies on patients with delayed graft function after kidney transplantation. J Nephrol 30: 289-295.

35. Puttarajappa C, Yabes J, Bei L, Shah N, Bernardo J, et al. (2013) Cancer risk with alemtuzumab following kidney transplantation. Clin Transplant 27: E264-271.

36. Hoogen MWV, Hesselink DA, Son WJV, Weimar W, Hilbrands LB (2013) Treatment of steroid-resistant acute renal allograft rejection with alemtuzumab. Am J Transplant 13: 192-196.

37. Vo AA, Petrozzino J, Yeung K, Sinha A, Kahwaji J, et al. (2013) Efficacy, outcomes, and cost-effectiveness of desensitization using IVIG and rituximab. Transplantation 95: 852-858.

38. Jordan SC, Choi J, Vo A (2015) Achieving incompatible transplantation through desensitization: Current perspectives and future directions. Immunotherapy 7: 377-398.

39. Vo AA, Choi J, Cisneros K, Reinsmoen N, Haas M, et al. ${ }^{(2014)}$ Benefits of rituximab combined with intravenous immunoglobulin for desensitization in kidney transplant recipients. Transplantation 98: 312319.

40. Woodle ES, Shields AR, Ejaz NS, Sadaka B, Girnita A, et al. (2015) Prospective iterative trial of proteasome inhibitor-based desensitization. Am J Transplant 15: 101-118.

41. Becker LE, Weritz B, Yi X, Weissmann MLG, Waldherr R, et al. (2015) Evolution of allograft fibrosis and function in kidney transplant recipients: ${ }^{\mathrm{A}}$ retrospective analysis of stable patients under $\mathrm{CNI}$ and mTORi. Transpl Int 28: 553-564.

42. Heemann U, Lutz J (2013) Pathophysiology and treatment options of chronic renal allograft damage. Nephrol Dial Transplant 28: 2438-2446. 
43. Sommerer C, Giese T, Meuer S, Zeier M (2010) New concepts to individualize calcineurin inhibitor therapy in renal allograft recipients. Saudi J Kidney Dis Transpl 21: 1030-1037.

44. Geddes CC, Jardine AG, Kingsmore D, Murio E, Buist L, et al. (2012) Five-year outcomes after a change from a CyA-based to a 'low-dose tacrolimus-based primary immunosuppression regimen for incident kidney transplants-The Glasgow experience. Clin Transpl pp. 95-102.

45. Kumar MSA, Saeed MI, Ranganna K, Malat G, Reodica NS, et al. (2008) Comparison of four different immunosuppression protocols without long-term steroid therapy in kidney recipients monitored by surveillance biopsy: Five-year outcomes. Transpl Immunol 20: 32-42.

46. Cheung CY, Chan HW, Liu YL, Chau KF, Li CS (2009) Long-term graft function with tacrolimus and CyA in renal transplantation: paired kidney analysis. Nephrology (Carlton) 14: 758-763.

47. Allison AC, Eugui EM (2005) Mechanisms of action of mycophenolate mofetil in preventing acute and chronic allograft rejection. Transplantation 80: S181-190.

48. Albano L, Berthoux F, Moal MC, Rostaing L, Legendre C, et al. (2009) Incidence of delayed graft function and wound healing complications after deceased-donor kidney transplantation is not affected by de novo everolimus. Transplantation 88: 69-76.

49. Ekberg H, Silva HT, Demirbas A, Vítko S, Nashan B, et al. (2007) Reduced exposure to calcineurin inhibitors in renal transplantation. N Engl J Med 357: 2562-2575.

50. Mühlbacher F, Neumayer HH, Castillo D, Stefoni S, Zygmunt AJ, et al. (2014) The efficacy and safety of CyA reduction in de novo renal allograft patients receiving sirolimus and corticosteroids: Results from an openlabel comparative study. Transpl Int 27: 176-186.

51. Bechstein WO, Paczek L, Wramner L, Squifflet JP, Zygmunt AJ, et al. (2013) A comparative, randomized trial of concentration-controlled sirolimus combined with reduced-dose tacrolimus or standard-dose tacrolimus in renal allograft recipients. Transplant Proc 45: 2133-2140.

52. Chan L, Greenstein S, Hardy MA, Hartmann E, Bunnapradist S, et al. (2008) Multicenter, randomized study of the use of everolimus with tacrolimus after renal transplantation demonstrates its effectiveness. Transplantation 85: 821-826.

53. Holdaas H, Rostaing L, Serón D, Cole E, Chapman J, et al. (2011) Conversion of long-term kidney transplant recipients from calcineurin inhibitor therapy to everolimus: A randomized, multicenter, 24-month study. Transplantation 92: 410-418.

54. Schena FP, Pascoe MD, Alberu J, Rial MC, Oberbauer R, et al. (2009) Conversion from calcineurin inhibitors to sirolimus maintenance therapy in renal allograft recipients: 24-month efficacy and safety results from the CONVERT trial. Transplantation 87: 233-242.

55. Lebranchu Y, Snanoudj R, Toupance O, Weestel PF, Ligny BH, et al. (2012) Five-year results of a randomized trial comparing de novo sirolimus and CyA in renal transplantation: The SPIESSER study. Am J Transplant 12: 1801-1810.

56. Chadban SJ, Eris JM, Kanellis J, Pilmore H, Lee PC, et al. (2014) A randomized, controlled trial of everolimus-based dual immunosuppression versus standard of care in de novo kidney transplant recipients. Transpl Int 27: 302-311.

57. Langer RM, Hené R, Vitko S, Christiaans M, Silva HT, et al. (2012) Everolimus plus early tacrolimus minimization: a phase III, randomized, open-label, multicentre trial in renal transplantation. Transpl Int 25 592-602.

58. Larson TS, Dean PG, Stegall MD, Griffin MD, Textor SC, et al. (2006) Complete avoidance of calcineurin inhibitors in renal transplantation: A randomized trial comparing sirolimus and tacrolimus. Am J Transplant 6: 514-522.

59. Flechner SM, Glyda M, Cockfield S, Grinyó J, Legendre C, et al. (2011) The ORION study: Comparison of two sirolimus-based regimens versus tacrolimus and mycophenolate mofetil in renal allograft recipients. Am J Transplant 11: 1633-1644.

60. Silva Jr HT, Cibrik D, Johnston T, Lackova E, Mange K, et al. Everolimus plus reduced-exposure csa versus mycophenolic acid plus standard- exposure csa in renal-transplant recipients. Am J Transplantation 10: 1401-1413.

61. Lebranchu Y, Thierry A, Toupance O, Westeel PF, Etienne I, et al. (2009) Efficacy on renal function of early conversion from CyA to sirolimus 3 months after renal transplantation: Concept study. Am J Transplant 9: 1115-1123.

62. Weir MR, Mulgaonkar S, Chan L, Shidban H, Waid TH, et al. (2011) Mycophenolate mofetil-based immunosuppression with sirolimus in renal transplantation: A randomized, controlled Spare-the-Nephron trial. Kidney Int 79: 897-907.

63. Fritsche L, Budde K, Dragun D, Einecke G, Diekmann F, et al. (2004) Testosterone concentrations and sirolimus in male renal transplant patients. Am J Transplant 4: 130-131.

64. Uchida J, Iwai T, Kuwabara N, Kabei K, Nishide S, et al. (2016) Clinical experience of late conversion from antimetabolites with standard exposure calcineurin inhibitors to everolimus with calcineurin inhibitor minimization in stable kidney transplant recipients with good renal function. Transplant proc 48: 775-780.

65. Campbell SB, Walker R, Tai SS, Jiang Q, Russ GR (2012) Randomized controlled trial of sirolimus for renal transplant recipients at high risk for nonmelanoma skin cancer. Am J Transplant 12: 1146-1156.

66. Budde K, Lehner F, Sommerer C, Arns W, Reinke P, et al. (2012) ZEUS Study Investigators. Conversion from CyA to everolimus at 4.5 months post-transplant: 3-year results from the randomized ZEUS study. Am J Transplant. 12: 1528-1540.

67. Euvrard S, Morelon E, Rostaing L, Goffin E, Brocard A, et al (2012) Sirolimus and secondary skin-cancer prevention in kidney transplantation. N Engl J Med 367: 329-339.

68. Knoll GA, Kokolo MB, Mallick R, Beck A, Buenaventura CD, et al. (2012) Effect of sirolimus on malignancy and survival after kidney transplantation: Systematic review and meta-analysis of individual patient data. BMJ 349: g6679.

69. Radtke J, Dietze N, Spetzler VN, Fischer L, Achilles EG, et al. (2016) Fewer cytomegalovirus complications after kidney transplantation by de novo use of mTOR inhibitors in comparison to mycophenolic acid. Transpl Infect Dis 18: 79-88.

70. Brennan DC, Legendre C, Patel D, Mange K, Wiland A, et al. (2011) Cytomegalovirus incidence between everolimus versus mycophenolate in de novo renal transplants: Pooled analysis of three clinical trials. Am J Transplant 11: 2453-2462.

71. Jacobi J, Prignitz A, Büttner M, Korn K, Weidemann A, et al. (2013) BK viremia and polyomavirus nephropathy in 352 kidney transplants; risk factors and potential role of mTOR inhibition. BMC Nephrol 14: 207.

72. Jouve T, Rostaing L, Malvezzi P (2016) Place of mTOR inhibitors in management of BKV infection after kidney transplantation. J Nephropathol 5: 1-7.

73. Messina M, Ariaudo C, Mella A, Cantaluppi V, Segoloni GP, et al. (2015) mTOR inhibitors for medical treatment of post-transplantation encapsulating peritoneal sclerosis: A favourable single center experience. J Nephrol 28: 245-249.

74. Frascà GM, D'Arezzo M, Ricciatti AM, Balestra E, Taruscia D, et al (2014) $\mathrm{m}$-TOR inhibitors may be useful in the treatment of encapsulating peritoneal sclerosis (EPS). J Nephrol 27: 587-590.

75. Sud R, Garry L, Spicer ST, Allen RD, Eris JM, et al. (2014) A role for everolimus in post-transplant encapsulating peritoneal sclerosis: First case report. Nephrology (Carlton) 19: 27-30.

76. Bertoni E, Larti A, Rosso G, Zanazzi M, Di Maria L, et al. (2011) Good outcomes with CyA very low exposure with everolimus high exposure in renal transplant patients. Nephrol 24: 613-618.

77. Carmellini M, Garcia V, Wang Z, Vergara M, Russ G (2015) Efficacy of everolimus with reduced-exposure CyA in de novo kidney transplant patients at increased risk for efficacy events: Analysis of a randomized trial. Nephrol 28: 633-639.

78. Gatault P, Bertrand D, Büchler M, Colosio C, Ligny BH, et al. (2016) Eight-year results of the Spiesser study, a randomized trial comparing de novo sirolimus and CyA in renal transplantation. Transpl Int 29: 41-50. 
79. Diekmann F, Dalmau AG, López S, Cofán F, Esforzado N, et al. (2007) Influence of sirolimus on proteinuria in de novo kidney transplantation with expanded criteria donors: Comparison of two CNI-free protocols. Nephrol Dial Transplant 22: 2316- 2321.

80. Flechner SM, Kurian SM, Solez K, Cook DJ, Burke JT, et al. (2004) De novo kidney transplantation without use of calcineurin inhibitors preserves renal structure and function at two years. Am J Transplant 4: 1776-1785.

81. Kreis H, Cisterne JM, Land W, Wramner L, Squifflet JP, et al. (2000) Sirolimus in association with mycophenolate mofetil induction for the prevention of acute graft rejection in renal allograft recipients. Transplantation 69: 1252-1260.

82. Flechner SM, Goldfarb D, Solez K, Modlin CS, Mastroianni B, et al. (2007) Kidney transplantation with sirolimus and mycophenolate mofetil-based immunosuppression: 5-year results of a randomized prospective trial compared to calcineurin inhibitor drugs. Transplantation 83: 883-892.

83. Paoletti E, Ratto E, Bellino D, Marsano L, Cassottana P, et al. (2012) Effect of early conversion from CNI to sirolimus on outcomes in kidney transplant recipients with allograft dysfunction. J Nephrol 25: 709-718.

84. Han F, Wu J, Huang H, Zhang X, He Q, et al. (2011) Conversion from CyA to sirolimus in chronic renal allograft dysfunction: A 4-year prospective study. Exp Clin Transplant 9: 42-49.

85. Tsai MK, Wu FL, Lai IR, Lee CY, Hu RH, et al. (2009) Decreased acute rejection and improved renal allograft survival using sirolimus and lowdose calcineurin inhibitors without induction therapy. Int J Artif Organs 32: 371-380.

86. Yamanaka K, Kakuta Y, Nakazawa S, Kato T, Abe T, et al. (2016) Induction immunosuppressive therapy with everolimus and low-dose tacrolimus extended-release preserves good renal function at 1 year after kidney transplantation. Transplantation Proceedings 48: 781-785.

87. Yoshimura N, Nakao T, Nakamura T, Harada S, Koshino K, et al. (2016) Effectiveness of the combination of everolimus and tacrolimus with high dosage of mizoribine for living donor-related kidney transplantation. Transplant proc 48:786-789.

88. Carmellini M, Collini A, Ruggieri G, Garosi G, Bernini M (2008) Excellent long-term results in de novo renal transplant recipients treated with proliferation signal inhibitors and reduced calcineurin inhibitors exposure. Transplant Proc 40: 1858-1861.

89. Huang H, Xie W, Wu J, Xu Y, Yu X, et al. (2014) Early conversion from calcineurin inhibitor to sirolimusto after renal transplantation: A prospective, open-label and non-randomized control study. Zhonghua Yi Xue Za Zhi 94: 3293-3297.

90. Kandaswamy R, Melancon JK, Dunn T, Tan M, Casingal V, et al. (2005) A prospective randomized trial of steroid-free maintenance regimens in kidney transplant recipients-an interim analysis. Am J Transplant 5: 1529-1536.

91. Salvadori M, Scolari MP, Bertoni E, Citterio F, Rigotti P, et al. (2009) Everolimus with very low-exposure CyA a in de novo kidney transplantation: A multicenter, randomized, controlled trial. Transplantation 88: 1194-1202.

92. Oh CK, Huh KH, Ha J, Kim YH, Kim YL, et al. (2015) Safety and efficacy of the early introduction of everolimus with reduced-exposure CyA a in de novo kidney recipients. Transplantation 99: 180-186.

93. Lee J, Lee JJ, Kim BS, Lee JG, Huh KH, et al. (2015) A 12-month single arm pilot study to evaluate the efficacy and safety of sirolimus in combination with tacrolimus in kidney transplant recipients at high immunologic risk. J Korean Med Sci 30: 682-687.

94. Su L, Tam N, Deng R, Chen P, Li H, et al. (2014) Everolimus-based calcineurin-inhibitor sparing regimens for kidney transplant recipients: A systematic review and meta-analysis. Int Urol Nephrol 46: 2035-2044.
95. Burkhalter F, Oettl T, Descoeudres B, Bachmann A, Guerke L, et al. (2012) High incidence of rejection episodes and poor tolerance of sirolimus in a protocol with early steroid withdrawal and calcineurin inhibitor-free maintenance therapy in renal transplantation: Experiences of a randomized prospective single-center study. Transplant Proc 44: 2961-2965.

96. Webster AC, Lee VW, Chapman JR, Craig JC (2006) Target of rapamycin inhibitors (sirolimus and everolimus) for primary immunosuppression of kidney transplant recipients: A systematic review and meta-analysis of randomized trials. Transplantation 81: 1234-1248.

97. Furian L, Baldan N, Margani G, Ekser B, Silvestre C, et al. (2007) Calcineurin inhibitor-free immunosuppression in dual kidney transplantation from elderly donors. Clin Transplant 21: 57-62.

98. Shaffer D, Langone A, Nylander WA, Goral S, Kizilisik AT, et al. (2003) A pilot protocol of a calcineurin-inhibitor free regimen for kidney transplant recipients of marginal donor kidneys or with delayed graft function. Clin Transplant 17: 31-34.

99. Pisani F, Buonomo O, Iaria G, Iorio B, Rizzello A, et al. (2004) Sirolimus in kidney transplantation from marginal donors. Transplant Proc 36: 495-496.

100. Cruzado JM, Bestard O, Riera L, Torras J, Vernet SG, et al. (2007) Immunosuppression for dual kidney transplantation with marginal organs: The old is better yet. Am J Transplant 7: 639-644.

101. Uslu A, Nart A, Taşli FA, Postaci H, Aykas A, et al. (2008) Sirolimusbased triple immunosupression with antithymocyte globulin induction in expanded criteria donor kidney transplantation. Nephrology (Carlton) 13: 80-6.

102. Luke PP, Nguan CY, Horovitz D, Gregor L, Warren J, et al. (2009) Immunosuppression without calcineurin inhibition: Optimization of renal function in expanded criteria donor renal transplantation. Clin Transplant 23: 9-15.

103. Boratynska M, Banasik M, Patrzalek D, Klinger M (2008) Impact of sirolimus treatment in kidney allograft recipients with prolonged cold ischemia times: 5-year outcomes. Exp Clin Transplant 6: 59-66.

104. Uchida J, Machida Y, Iwai T, Kuwabara N, Kabei K, et al. (2014) Conversion of stable $\mathrm{ABO}$-incompatible kidney transplant recipients from mycophenolate mofetil with standard exposure calcineurin inhibitors (CNIs) to everolimus with very low exposure CNIs-a shortterm pilot study. Clin Transplant 28: 80-87

105. Gaber AO, Kahan BD, Buren CV, Schulman SL, Scarola J, et al. (2008) Comparison of sirolimus plus tacrolimus versus sirolimus plus CyA in high-risk renal allograft recipients: Results from an open-label, randomized trial. Transplantation 86: 1187-1195.

106. Lo A, Egidi MF, Gaber LW, Amiri HS, Vera S, et al. (2004) Comparison of sirolimus-based calcineurin inhibitor-sparing and calcineurin inhibitorfree regimens in cadaveric renal transplantation. Transplantation. 77: 1228-1235.

107. Jürgensen JS, Ikenberg R, Greiner RA, Hösel V (2015) Cost-effectiveness of modern mTOR inhibitor based immunosuppression compared to the standard of care after renal transplantation in Germany. Eur J Health Econ 16: 377-390.

108. Lim LM, Kung LF, Kuo MC, Kuo HT (2016) Risk factors associated with mammalian target of rapamycin inhibitor withdrawal in kidney transplant recipients. Transplant proc 48: 790-793.

109. Ekberg H, Kyllönen L, Madsen S, Grave G, Solbu D, et al. (2007) Increased prevalence of gastrointestinal symptoms associated with impaired quality of life in renal transplant recipients. Transplantation 83: 282-289. 